\title{
Chemical degradation kinetics of fibrates: bezafibrate, ciprofibrate and fenofibrate
}

\author{
Marcelo Antonio de Oliveira*, Gerliane Damázio da Silva, Michele Soares Tacchi Campos
}

North University Center of Espirito Santo, Federal University of Espirito Santo, São Mateus, ES, Brazil

\begin{abstract}
Fibrates are drugs used for the treatment of hypertriglyceridemia and for the prevention of atherosclerosis. Three drugs in the fibrate class, ciprofibrate, fenofibrate and bezafibrate, were chosen for this study because their raw materials are readily available and because scientific publications on these compounds is limited. To evaluate their intrinsic stability, the drugs were exposed to a test condition (temperature, oxidation, UV light exposure, hydrolysis at different $\mathrm{pH}$ values and metal ions in solution) and then were subjected to analysis by HPLC. The samples were run on a C18 column, with a flow rate of $1.0 \mathrm{~mL} \mathrm{~min}^{-1}$ in a mobile phase consisting of methanol: $0.01 \%$ phosphoric acid $\mathrm{v} / \mathrm{v}(80: 20)$, with variable detection wavelengths in the UV spectra. The analysis methodology showed satisfactory performance parameters. The three drugs were very unstable, degrading in each of the conditions evaluated. The test conditions of acid and basic hydrolysis showed the most significant degradation. The results demonstrated that the drugs in this class are unstable. Based on these experimentally determined degradation kinetics, it is easy to understand and emphasize the importance of the lack of liquid dosage forms on the market for fibrates because of their instability.
\end{abstract}

Uniterms: Hypertriglyceridemia/fibrates. Fibrates stability/study. Fibrates degradation products/High Perfomance Liquid Chromatography (HPLC). Fibrates/Degradation kinetics.

\section{INTRODUCTION}

Fibrates are drugs used for the treatment of hypertriglyceridemia and for the prevention of atherosclerosis, and are represented by the following compounds: clorfibrate, ciprofibrate, bezafibrate, fenofibrate and geozila. Fibrates decrease triglyceride levels and increase HDL-C levels, the latter effect is more pronounced in patients with hypertriglyceridemia. The effect on LDL-C levels varies. They may reduce LDL-C levels in patients with low triglycerides, but may paradoxically increase levels for patients with high triglyceride levels. Fibrates also significantly reduce the levels of highly atherogenic remnant lipoproteins, and are more efficient than statins in doing so (Schulz, 2006).

Among the fibrates, three drugs were chosen for the execution of this project: ciprofibrate, fenofibrate and bezafibrate (Figure 1). The drugs were chosen based on the availability of raw materials and evidence of few

\footnotetext{
*Correspondence: M. A. Oliveira. Centro Universitário Norte do Espírito Santo. Universidade Federal Espirito Santo. Rodovia BR 101 Norte, km 60, 29932-540 - São Mateus - ES, Brasil. E-mail: oliveirama.ufes@gmail.com
}

scientific publications regarding the drugs on the subject of research.

Some analytical methods have been developed for the analysis of ciprofibrate, fenofibrate and bezafibrate by HPLC/UV (Nascimento et al., 2011; Salama et al., 2011; Jain et al., 2012; Kumbhar et al., 2013; Wei et al., 2008). The vast majority of these analytical methodologies used reverse phase columns, mainly octadecyl silane, with a controlled acidic $\mathrm{pH}$ solution for the mobile phase and detection in the ultraviolet range.

Few articles have been published on the stability of the chosen fibrates (Salama et al., 2011; Jain et al., 2012; Kumbhar et al., 2013), and none were found that identified degradation products, the hypothesized route of degradation, or studied the degradation kinetics of these drugs. Excipients are chosen for pharmaceutical formulations based on the stability data, for the purpose of obtaining a more stable formulation. It is noted that fenofibrate is an ester and bezafibrate is an amide, which makes them very susceptible to hydrolysis reactions.

According to the biopharmaceutics classification system (BCS), fibrates are class II drugs with low solubility and high permeability (Benet, 2006). Any 




(a)

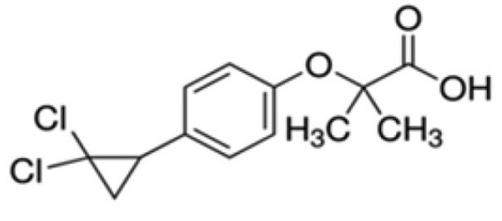

(b)<smiles>CC(C)OC(=O)C(C)(C)Oc1ccc(C(=O)c2ccc(Cl)cc2)cc1</smiles>

(c)

FIGURE 1 - Molecular structure of (a) bezafibrate, (b) ciprofibrate, and (c) fenofibrate.

change in the quality of a class II drug caused by stability problems directly influences the bioavailability of the drug (Yoshida et al., 2010, 2011).

The HPLC analytical methodology must be optimized for the determination of the parent drug as well as possible degradation products obtained under conditions of intrinsic stability testing. Chromatographic performance parameters should be evaluated after technical optimization, such as the retention factor ( $\mathrm{k}$ '), number of theoretical plates/column $(\mathrm{N})$, resolution $(\mathrm{Rs})$ and tail factor or asymmetry (T) (ANVISA, 2010).

In developing a pharmaceutical formulation, it is important to determine the intrinsic stability of the drug to predict possible reactions and degradation products (Silva et al., 2009). The stability of the substance should be evaluated for a number of stressors including temperature changes, oxidation, UV light exposure and hydrolysis at different $\mathrm{pH}$ values. The photostability can be evaluated by subjecting the compound to UV irradiation. Some degradation pathways can be complex. Not all decomposition products formed under the more drastic conditions of intrinsic stability are seen in drugs subjected to the official conditions of stability studies (USP, 2014; Silva et al., 2009; ANVISA, 2005).

In accordance with the regulations, it is important to exhaust the possibilities of all drug reactions that have not been explored fully (Silva et al., 2009; USP, 2014; ANVISA, 2005). It is also important to propose degradation mechanisms, study the kinetics of the reactions, and evaluate the pharmaceutical formulation and compare it with the choice of excipients used.

To research the degradation products, drugs are subjected to drastic conditions including neutral, acid or basic hydrolysis, oxidation with peroxide, exposure to UV light, degradation with metal ions $\left(\mathrm{FeSO}_{4}\right)$ and heat (ANVISA, 2005, 2013). The analysis must be performed by HPLC and probabilistic mechanisms of possible degradation reactions should be proposed.

Kumbhar et al. (2013) reports that fenofibrate undergoes rapid degradation through acid and basic hydrolysis, and under hydrogen peroxide-mediated oxidation. Jain et al. (2012) reports that ciprofibrate is unstable to acid hydrolysis, basic hydrolysis and under oxidation.

Degradation kinetics are also used to assess the stability of drug is where the extent of degradation, $\mathrm{t}_{90}$ (time to degrade $10 \%$ of the drug), degradation rate, easiness of degradation (which is related to the Energy Activation of the reaction), and it becomes interesting in comparison of stress conditions establishing a proportionality logic and for chemical reactions. Thus, intrinsic stability and kinetic studies are key components in the discovery of potential drug degradation products, even though these products may not occur under normal medication storage conditions (Yoshida et al., 2010, 2011).

After defining the conditions under which the drugs degrade, we conducted a study that included different collection times in order to determine the progression of the degradation reactions. Then chemical and mathematical studies were conducted to determine the activation energy $\left(\mathrm{E}_{\mathrm{a}}\right)$, pre-exponential factor, rate of reaction $(k)$ and finally, estimates for the time required to degrade $10 \%$ of the drug $\left(t_{90}\right)$ in a specific condition, usually at $298 \mathrm{~K}$, which is the standard storage temperature for pharmaceutical products. The $t_{90}$ is often interpreted as the shelf-life of a drug. This is calculated through an extrapolation of the Arrhenius equation, and the value determines the drug lifetime at 298 K (Cides et al., 2006; Yoshida et al., 2010, 2011).

The following equations can be used to describe the observed kinetics of degradation in solution:

\begin{tabular}{ccc}
\hline \multicolumn{3}{c}{ ORDER } \\
\hline ZERO & FIRST & SECOND \\
\hline $\mathrm{C}=-k \mathrm{~T}+\mathrm{C}_{\mathrm{o}}$ & $\log \mathrm{C}=-k \mathrm{~T} / 2.303$ & $1 / \mathrm{C}=k \mathrm{~T}+1 / \mathrm{C}_{\mathrm{o}}$ \\
$\mathrm{t}_{90}=\left(0.1 \times \mathrm{C}_{\mathrm{o}}\right) / k$ & $+\log \mathrm{C}_{\mathrm{o}}$ & $\mathrm{t}_{90}=1 /\left(9 \times k \times \mathrm{C}_{\mathrm{o}}\right)$ \\
& $\mathrm{t}_{90}=0.105 / k$ & \\
\hline
\end{tabular}

$\mathrm{C}=$ concentration $(\%) ; k=$ rate constant $\left(\mathrm{s}^{-1}\right) ; \mathrm{C}_{\mathrm{o}}=$ initial concentration; $\mathrm{t}=$ time $(\mathrm{s})$.

Arrhenius equation (1):

$$
\log k=-\mathrm{Ea} \times \frac{1}{2.303 \times \mathrm{RT}}+\log \mathrm{A}
$$

where: $k=$ rate constant, $\mathrm{Ea}=$ activation energy, $\mathrm{A}=$ pre- 
exponential factor, $\mathrm{T}=$ temperature in Kelvin, $\mathrm{R}=$ gas constant $\left(8.314 \mathrm{~J} \mathrm{~mol}^{-1} \mathrm{~K}^{-1}\right)$.

The aim of this paper was to develop and optimize an analytical HPLC method for determination of fibrates and possible degradation products, to evaluate the intrinsic stability of these drugs under stress conditions, and to study the kinetics of degradation of these drugs that are so susceptible to chemical reactions.

\section{MATERIAL AND METHODS}

\section{Development and optimization of an analytical methodology for HPLC determination}

Analyses were carried out using a HPLC (Waters ${ }^{\circledR}$ ) equipped with a UV/DAD detector, autoinjector, and oven. The separation methodology was based on reverse phase chromatography, using an octadecyl silane column (RP18) with a length of $30 \mathrm{~cm}$ to facilitate the separation of possible degradation products, and an UV/DAD detector to facilitate the identity of the degradation products, and reveal possible co-elutions.

\section{Performance Parameters}

The performance parameters (system suitability) were calculated according to formulas described by the Brazilian Pharmacopoeia (Brazil, 2010) for the retention factor $\left(k^{\prime}\right)$, peak asymmetry (As), number of theoretical plates $(\mathrm{N})$ and resolution $(\mathrm{Rs})$.

\section{Evaluation of intrinsic stability}

The initial conditions used to evaluate the intrinsic stability of bezafibrate, ciprofibrate and fenofibrate were:

- Dry heat: $20 \mathrm{mg}$ of each drug was dissolved in methanol and subjected to dry heat in an oven at $323 \mathrm{~K}$ for 4 hours. After this procedure, the samples were diluted in methanol to a concentration of $0.01 \mathrm{mg} \mathrm{mL}^{-1}$.

- Neutral hydrolysis: $20 \mathrm{mg}$ of each drug was dissolved in methanol. $20 \mathrm{~mL}$ of water was added and the solution was incubated in a water bath at $323 \mathrm{~K}$ for 4 hours. After this procedure, the samples were diluted in methanol to a concentration of $0.01 \mathrm{mg} \mathrm{mL}^{-1}$.

- Alkaline hydrolysis: $20 \mathrm{mg}$ of each drug was dissolved in methanol. $20 \mathrm{~mL}$ of $0.1 \mathrm{M} \mathrm{NaOH}$ was added and the solution was incubated in a water bath at $323 \mathrm{~K}$ for 4 hours. After this procedure, the samples were diluted in methanol to a concentration of $0.01 \mathrm{mg} \mathrm{mL}^{-1}$.
- Acid hydrolysis: $20 \mathrm{mg}$ of each drug was dissolved in methanol. $20 \mathrm{~mL}$ of $0.1 \mathrm{M} \mathrm{HCl}$ was added and the solution was incubated in a water bath at $323 \mathrm{~K}$ for 4 hours. After this procedure, the samples were diluted in methanol to a concentration of $0.01 \mathrm{mg} \mathrm{mL}^{-1}$.

- Oxidation: $20 \mathrm{mg}$ of each drug was dissolved in methanol. $20 \mathrm{~mL}$ of $3 \%$ hydrogen peroxide (v/v) was added and the solution was incubated in a water bath at $323 \mathrm{~K}$ for 4 hours. After this procedure, the samples were diluted in methanol to a concentration of $0.01 \mathrm{mg} \mathrm{mL}^{-1}$.

- $\quad$ Exposure to ultraviolet light: $20 \mathrm{mg}$ of each drug was dissolved in methanol and placed in an UV radiation chamber under a $254 \mathrm{~nm}$ lamp for 4 hours. After this procedure, the samples were diluted in methanol to a concentration of $0.01 \mathrm{mg} \mathrm{mL}^{-1}$.

- Solution with metal ions $\left(\mathrm{FeSO}_{4}\right): 20 \mathrm{mg}$ of each drug was dissolved in methanol. $20 \mathrm{~mL}$ of a $0.05 \mathrm{M}$ $\mathrm{FeSO}_{4}$ solution was added and the resulting solution was incubated in the water bath at $323 \mathrm{~K}$ for 4 hours. After this procedure, the samples were diluted in methanol to a drug concentration of $0.01 \mathrm{mg} \mathrm{mL}^{-1}$. After being exposed to the stress conditions and being diluted as described above, the samples were analyzed by HPLC.

\section{Degradation kinetics studies}

After the degradation studies, drugs were subjected to acid or base hydrolysis at $323,333,343$ or $353 \mathrm{~K}$, conditions under which the drugs underwent further degradation. Samples were collected after 4, 5, 6 and 7 hours. The order of the degradation reactions was established according to the models of zero, first and second order kinetics.

Once each result was set to the best fit model (zero, first or second order), it was possible to calculate the degradation rate $(k)$ for each temperature with the aid of the linear correlation coefficient $(\mathrm{r})$.

Once the degradation rates $(k)$ were calculated at each temperature, it became possible to determine, with the help of the Arrhenius equation, $k$ at $298 \mathrm{~K}$ and thus indicate how long the drug takes to degrade $10 \%\left(\mathrm{t}_{90}\right)$. This is one way to determine the expiration date of a drug or medicament, also called $t_{90}$, or shelf-life.

\section{RESULTS AND DISCUSSION}

Chromatographic conditions were optimized for analysis of the drugs bezafibrate, ciprofibrate and fenofibrate using a mobile phase consisting of methanol 
and $0.01 \%$ phosphoric acid (80:20\% v/v); octadecyl silane column $(250 \times 4.6 \mathrm{~mm} ; 5 \mu \mathrm{m})$; wavelengths for bezafibrate $(254 \mathrm{~nm})$, ciprofibrate $(236 \mathrm{~nm})$, fenofibrate $(290 \mathrm{~nm})$; flow rate of $1.0 \mathrm{ml} \mathrm{min}{ }^{-1}$; temperature $303 \mathrm{~K}$; injection volume of $20 \mu \mathrm{L}$, and 20 minutes analysis of analysis.

After the HPLC analysis method was optimized, the performance parameters were determined for each compound: bezafibrate $\left(\mathrm{k}^{\prime}=0.67\right.$; As $=1.41, \mathrm{~N}=4299$ plates/column), ciprofibrate ( $\mathrm{k}^{\prime}=1.09$; As $=1.35, \mathrm{~N}=$ 6052 plates/column; $\mathrm{Rs}=3.95)$ and fenofibrate $\left(\mathrm{k}^{\prime}=3.51\right.$; As $=1.07, \mathrm{~N}=13.258$ plates/column; Rs $=17.77)$. These performance parameters were shown to be satisfactory according to the limits set for each parameter, which were $\mathrm{k}^{\prime}$ (retention factor) $>0.5, \mathrm{~N}$ (theoretical plates) $>2.000$, $\mathrm{T}$ (tailing factor) $\leq 2$, and Rs (resolution) $>2$ (Ribani et al., 2004).

Under these conditions, the retention times differed for each of the compounds and were $4.31 \mathrm{~min}$ for bezafibrate, $5.4 \mathrm{~min}$ for ciprofibrate and $11.6 \mathrm{~min}$ for fenofibrate. The three drugs were shown to be very unstable and degraded in all the conditions used in the intrinsic stability studies. The most significant reduction in peak area after submission to stress conditions was due to acid and basic hydrolysis. In light of these results for intrinsic stability, the degradation kinetics were evaluated under the acid and basic hydrolysis conditions, initially at temperatures of $323 \mathrm{~K}, 333 \mathrm{~K}, 343 \mathrm{~K}$ and $353 \mathrm{~K}$.

For bezafibrate and ciprofibrate, kinetic studies of drug degradation during acid and basic hydrolysis showed no proportional relationship between time and temperature, and the degradation studies were not reproducible. These results demonstrate the difficulty in deciphering the intermediate products of degradation kinetics, and such degradation was impossible to be fit to kinetic models. Previous studies of degradation under thermal analysis by TG (thermogravimetry) also were not reproducible for the experimentally determined dynamic TG or the isothermal TG. This lack of reproducibility of results when submitting bezafibrate and ciprofibrate to stress conditions indicates a complexity in both degradation processes.

There are no reports in the literature of possible mechanisms of degradation to bezafibrate and ciprofibrate. According to the molecular structures of each drug, it is possible to understand the complexity of these degradations. For bezafibrate, possible reactions under stress conditions could happen, such as: the ether group can suffer breaks in the chain when under acid hydrolysis; the aromatic halide group can undergo hydroxylation forming a phenol; and amide group can undergo hydrolysis, which is favored at basic or acid medium, resulting in alcohol and carboxylic acid. For ciprofibrate, under stress conditions, the ether group may rupture in the chain when under acid hydrolysis; the halide group can be converted into the alkene under basic hydrolysis, where it has a heated alcoholic solution and an inorganic base; and halide group, which is cyclic, may undergo elimination under basic hydrolysis obtaining an alicyclic hydrocarbon.

For fenofibrate, the kinetic degradation studies showed a significant decrease in peak area after acid and basic hydrolysis. Similar to the results for bezafibrate and ciprofibrate, under acid hydrolysis conditions no reproducible results were observed, and so it was not possible to make mathematical adjustments. This difficulty of adjusting the kinetic data in acid hydrolysis could be related to possible reactions that can happen, such as: the ketone group can react reversibly with the methanol used when under acid hydrolysis, forming "acetals"; the ether group can suffer breaks in the chain when under acid hydrolysis; the ester group can undergo hydrolysis, which may be favored in acid medium, resulting in an alcohol and a carboxylic acid; and even the aromatic halide group can undergo hydroxylation forming a phenol.

For fenofibrate, after basic hydrolysis, the results fit the model well and were reproducible. Figure 2 shows the chromatograms of fenofibrate kinetic studies after basic hydrolysis at different temperatures and exposure times. The possible mechanism of fenofibrate degradation reaction seems to be related to the characteristic reaction grouping ester hydrolysis. This mechanism has been described by Kumbhar et al. (2013) and Salama et al. (2011), and in view of the mathematical adjustment degradation models, this mechanism seems to be the only form of drug degradation in this stress condition.

The values related to the fit of the fenofibrate kinetic degradation data to the zero, first and second order mathematical models at $323,333,343$ and $353 \mathrm{~K}$ are described in Table I.

Analysis of the calculated linear regression coefficient ( $r$ ), suggested that the degradation kinetics of fenofibrate versus temperature are best described as a first order reaction, so the reaction rate depends on a single factor, which can be a reactant or product involved in the reaction (Brown et al., 2005).

After the reaction order was determined, the degradation rate constants were calculated for each temperature: $k_{323 \mathrm{~K}}=0.148797926, k_{333 \mathrm{~K}}=0.181610946$, $k_{343 \mathrm{~K}}=0.381299703$, and $k_{353 \mathrm{~K}}=0.591997704$. However, it was also possible to calculate $\mathrm{k} 298 \mathrm{~K}$, which was 


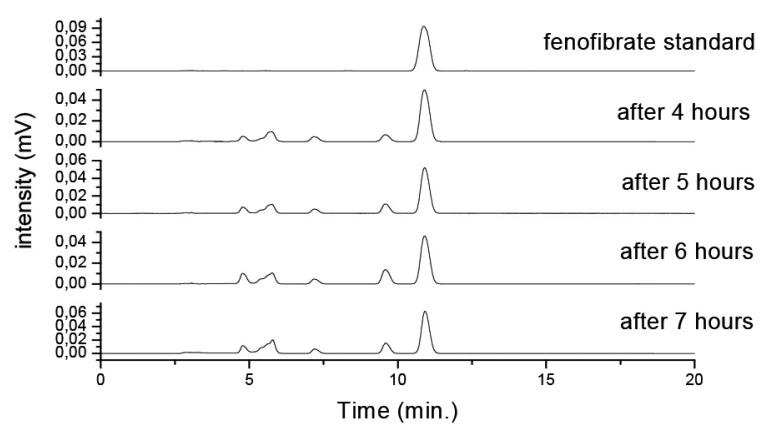

$323 \mathrm{~K}$ in $0.1 \mathrm{M} \mathrm{NaOH}$

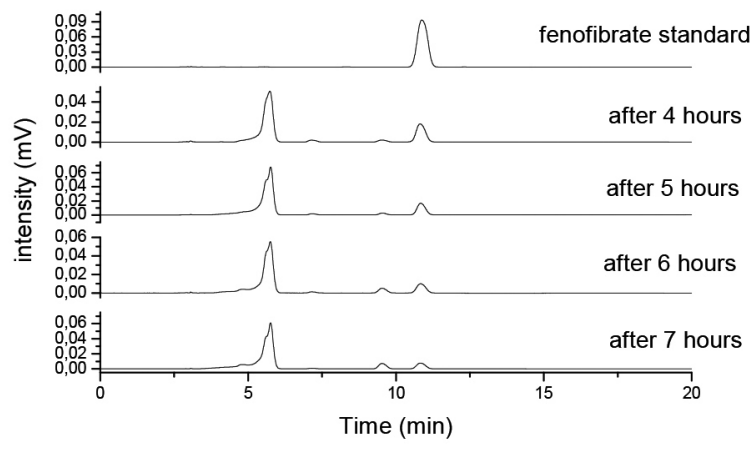

$343 \mathrm{~K}$ in $0.1 \mathrm{M} \mathrm{NaOH}$

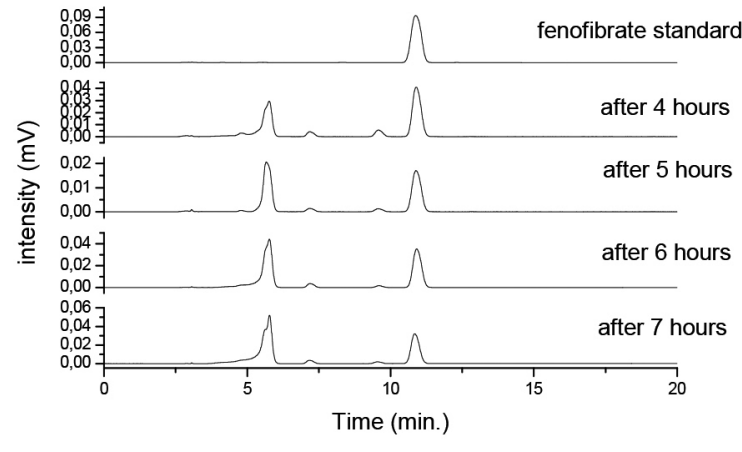

$333 \mathrm{~K}$ in $0.1 \mathrm{M} \mathrm{NaOH}$

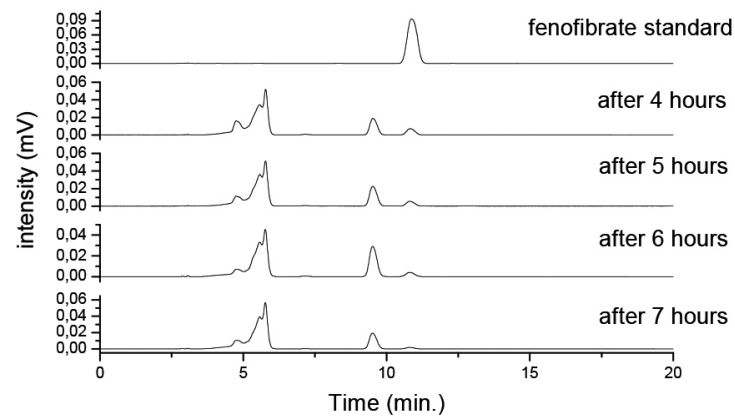

$353 \mathrm{~K}$ in $0.1 \mathrm{M} \mathrm{NaOH}$

FIGURE 2 - Chromatograms of the fenofibrate solution before (standard) and after 4, 5, 6 or 7 hours of basic hydrolysis at 323 , 333,343 or $353 \mathrm{~K}$.

0.031406672 . Thus, $\mathrm{t} 90$ was 3.34 hours. This means that after 3.34 hours in $0.1 \mathrm{M} \mathrm{NaOH}$, or equivalent $\mathrm{pH}$, the drug has degraded $10 \%$.

Figure 3 shows the plot of Arrhenius equation $\log \mathrm{k} \times 1 / \mathrm{T}$ function. The slope of the line is defined by the equation $\mathrm{E}_{\mathrm{a}}(2,303 \times \mathrm{R})^{-1}$, before it was possible to calculate the activation energy, so being $\mathrm{E}_{\mathrm{a}}=455.14 \mathrm{~J} \mathrm{~mol}^{-1}$ for the reaction of fenofibrate degradation.

For ciprofibrate, after evaluations of possible degradation products (DP) formed in the reaction, it was possible to study the kinetics of formation of these degradation products formed upon exposure to acid hydrolysis. Thus, the kinetic studies indicated a mathematical fit on the kinetics of formation of a DP (retention time $=6.61 \mathrm{~min}$ ) of ciprofibrate in acid medium. Figure 4 shows chromatograms of ciprofibrate kinetic study in acid hydrolysis, noting that the kinetic studies were performed for the degradation product formed in $6.61 \mathrm{~min}$.

The values reported in Table II show the mathematical fits of the zero, first and second order models of a ciprofibrate degradation product at temperatures of $323 \mathrm{~K}, 333 \mathrm{~K}, 343 \mathrm{~K}$ and $353 \mathrm{~K}$. It can be observed from
Table II that the best fit is the first order model, where the correlation coefficient was the closest to 1.000 , thus defining the order of the reaction. The rate constants were calculated for each temperature: $k_{323 \mathrm{~K}}=68644.24, k_{333 \mathrm{~K}}$ $=104592.10, k_{343 \mathrm{~K}}=137831.45$ and $k_{353 \mathrm{~K}}=235535.56$. Using the Arrhenius Equation graphical method (Figure 6) it was possible to calculate $k$ at $298 \mathrm{~K}$, which was 20812.63. The Arrhenius equation was used to determine the activation energy $\left(E_{a}\right), E_{a}=370.88 \mathrm{~J} \mathrm{~mol}^{-1}$ to form of the degradation product of ciprofibrate.

\section{CONCLUSIONS}

The HPLC analysis method was optimized by introducing appropriate performance parameters for the three drugs.

The three drugs have proved extremely unstable in liquid media, undergoing reactions in each of the tested stress conditions. The most significant instability was related to acid and basic hydrolysis.

It was not possible to study the kinetics of bezafibrate and ciprofibrate degradation since the degradation of these drugs exhibits no proportionality between time 
TABLE I - Kinetic data for the degradation of fenofibrate under basic hydrolysis at 323, 333, 343 and $353 \mathrm{~K}$

\begin{tabular}{lcccc}
\hline \multirow{2}{*}{ Temperature (K) } & Parameter & \multicolumn{3}{c}{ Order } \\
\cline { 2 - 4 } 323 & $\mathrm{a}$ & -10.12976 & First & Second \\
\cline { 2 - 4 } & $\mathrm{b}$ & 96.91408 & -0.06461 & 0.00231 \\
& $\mathrm{r}$ & -0.97008 & 1.98355 & 0.010441 \\
333 & $\mathrm{a}$ & -10.45412 & -0.97819 & 0.98616 \\
\hline \multirow{3}{*}{343} & $\mathrm{~b}$ & 94.03265 & -0.07886 & 0.00357 \\
& $\mathrm{r}$ & -0.95643 & 1.96967 & 0.01052 \\
& $\mathrm{a}$ & -13.86424 & -0.97922 & 0.99558 \\
\hline \multirow{3}{*}{353} & $\mathrm{~b}$ & 90.43891 & -0.16557 & 0.01754 \\
& $\mathrm{r}$ & -0.94528 & 1.96678 & 0.00065 \\
& $\mathrm{a}$ & -14.74440 & -0.99370 & 0.95795 \\
\hline
\end{tabular}

The data were best fit to a line of type $\mathrm{Y}=\mathrm{a} \mathrm{X}+\mathrm{b}$, where $\mathrm{a}$ is the slope, $\mathrm{b}$ is the $\mathrm{y}$-intercept and $\mathrm{r}$ is the linear regression coefficient.

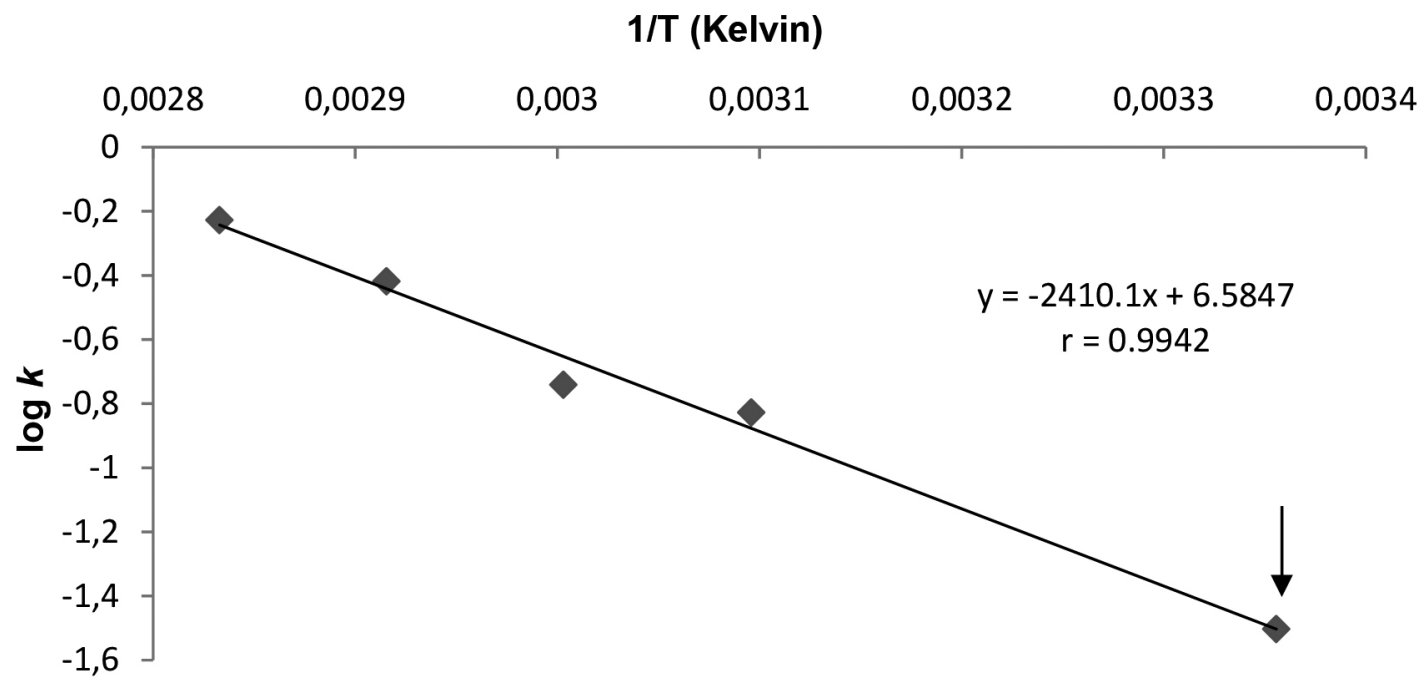

FIGURE 3 - Arrhenius equation graph extrapolated to $298 \mathrm{~K}$ for the drug fenofibrate. The arrow identifies $k_{298 \mathrm{~K}}$.

and temperature, and therefore could not be fit to kinetic models. However, it was possible to study the kinetics of the formation of a ciprofibrate degradation product with an $\mathrm{E}_{\mathrm{a}}$ of $370.88 \mathrm{~J} \mathrm{~mol}^{-1}$.

In the evaluation of fenofibrate basic hydrolysis degradation kinetics, the reaction was shown to be first order with a $t_{90}$ value of 3.34 hours. These analyses demonstrate the instability of the drug when exposed to $0.1 \mathrm{M} \mathrm{NaOH}$ or an equivalent $\mathrm{pH}$.

The absence of liquid dosage forms for fibrates on the market can be understood given the instability of the drugs as we have shown by degradation and kinetic studies.

\section{ACKNOWLEDGMENTS}

Financial support for this research was provided by FAPES (Foundation for supporting research of the Espirito Santo) and CNPq (National Counsel of Technological and Scientific Development). 


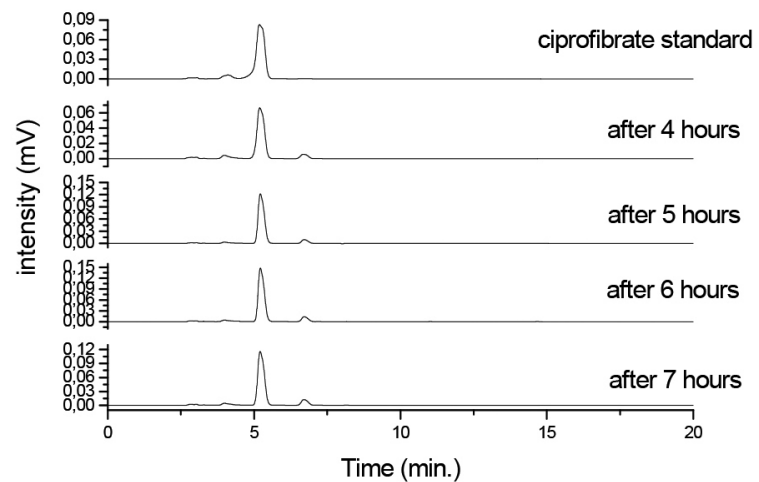

$323 \mathrm{~K}$ in $0.1 \mathrm{M} \mathrm{HCl}$

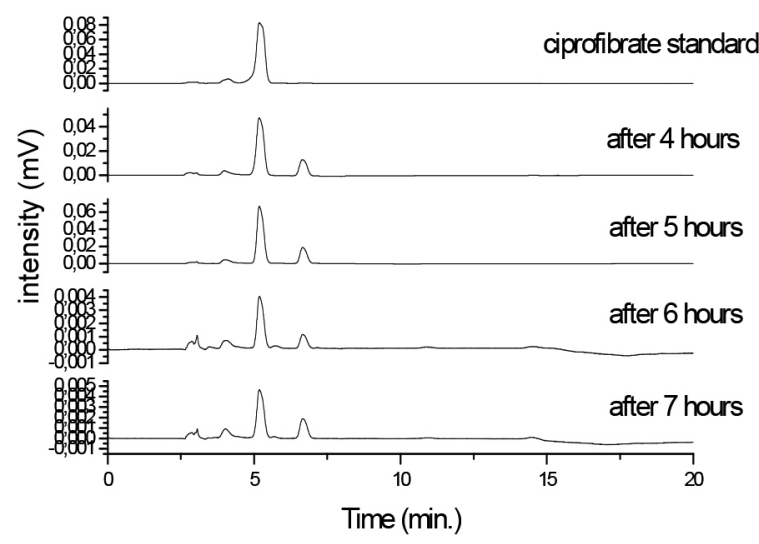

$343 \mathrm{~K}$ in $0.1 \mathrm{M} \mathrm{HCl}$

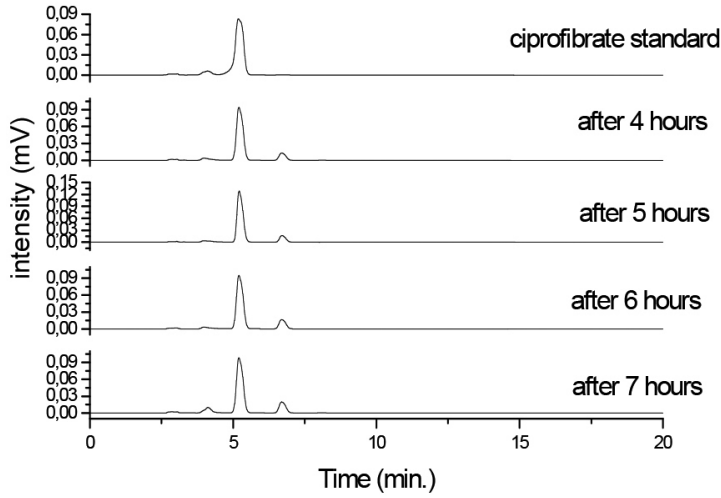

$333 \mathrm{~K}$ in $0.1 \mathrm{M} \mathrm{HCl}$

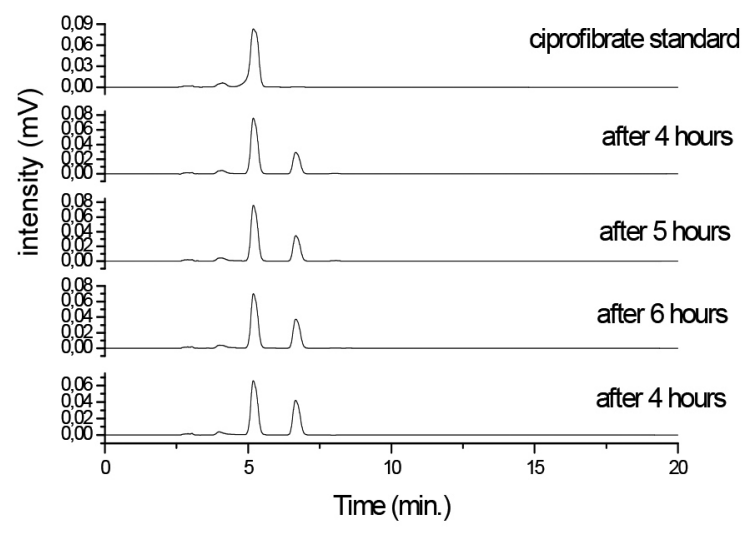

$353 \mathrm{~K}$ in $0.1 \mathrm{M} \mathrm{HCl}$

FIGURE 4 - Chromatograms of the ciprofibrate solution before (standard) and after 4, 5, 6 or 7 hours under acid hydrolysis at temperatures of $323,333,343$ and $353 \mathrm{~K}$.

TABLE II - Kinetic data for ciprofibrate degradation under acid hydrolysis at 323, 333, 343 or $353 \mathrm{~K}$

\begin{tabular}{lcccc}
\hline \multirow{2}{*}{ Temperature (K) } & \multirow{2}{*}{ Parameter } & \multicolumn{3}{c}{ Order } \\
\cline { 2 - 4 } & & Zero & First & Second \\
\hline 323 & $\mathrm{a}$ & 29806.44521 & 0.10016 & $-1.63613 \mathrm{E}-06$ \\
& $\mathrm{~b}$ & -3554.958904 & 4.63585 & $1.57726 \mathrm{E}-05$ \\
& $\mathrm{r}$ & 0.97959 & 0.92342 & -0.91602 \\
\hline 333 & $\mathrm{a}$ & 45415.58904 & 0.05794 & $-5.17395 \mathrm{E}-07$ \\
& $\mathrm{~b}$ & 9593.80822 & 5.09438 & $6.75259 \mathrm{E}-06$ \\
& $\mathrm{r}$ & 0.99340 & 0.99350 & -0.99265 \\
\hline 343 & $\mathrm{a}$ & 59848.65385 & 0.07978 & $-5.78635 \mathrm{E}-07$ \\
& $\mathrm{~b}$ & 41.63462 & 5.06706 & $6.38697 \mathrm{E}-06$ \\
& $\mathrm{r}$ & 1.00000 & 0.99744 & -0.98889 \\
\hline 353 & $\mathrm{a}$ & 102273.363 & 0.04994 & $-1.95 \mathrm{E}-07$ \\
& $\mathrm{~b}$ & 30729.60274 & 5.50056 & $2.76459 \mathrm{E}-06$ \\
& $\mathrm{r}$ & 0.98866 & 0.99517 & -0.99032 \\
\hline
\end{tabular}

The data were best fit to a line of type $\mathrm{Y}=\mathrm{a} \mathrm{X}+\mathrm{b}$, where $\mathrm{a}$ is the slope, $\mathrm{b}$ is the $\mathrm{y}$-intercept and $\mathrm{r}$ is the linear regression coefficient. 


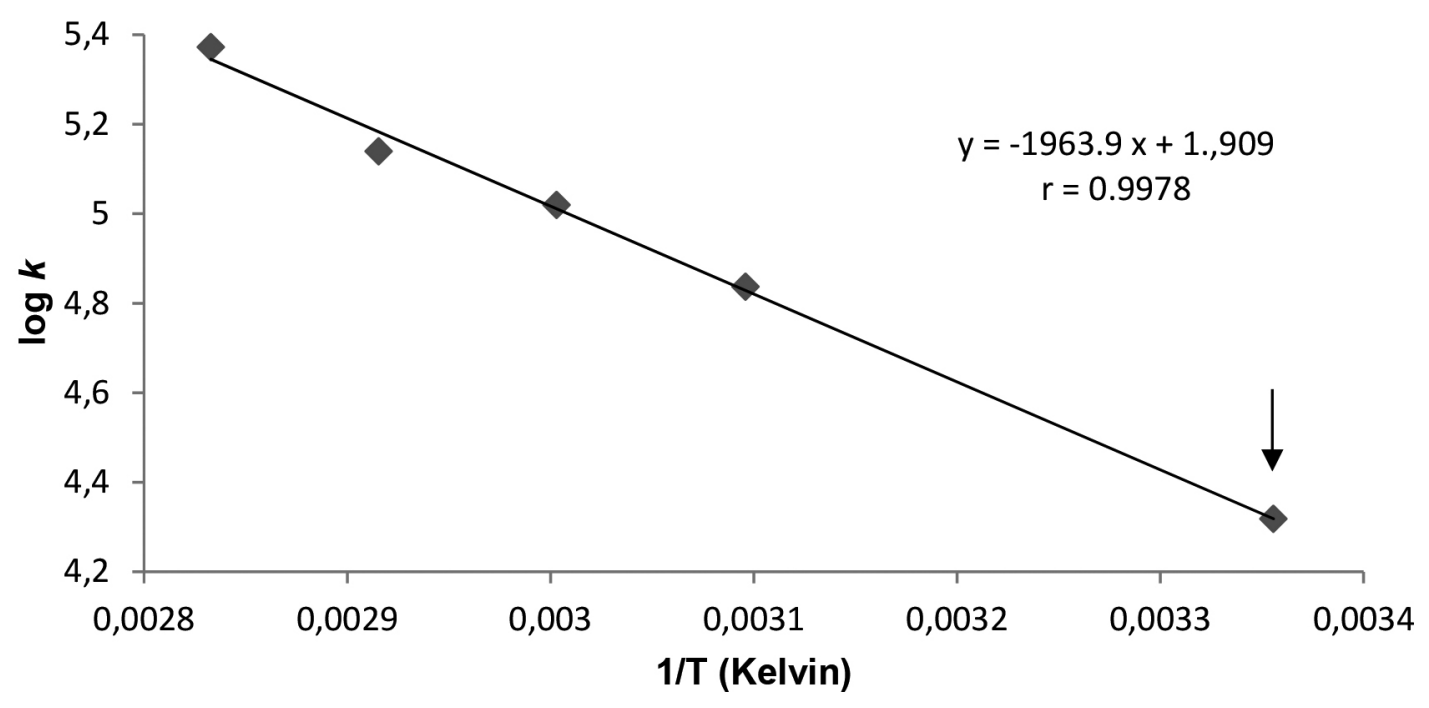

FIGURE 5 - Graph of the Arrhenius equation extrapolated to $298 \mathrm{~K}$ for a ciprofibrate degradation product. The arrow identifies $k_{298 \mathrm{~K}}$.

\section{REFERENCES}

BENET, L.Z. Can the BCS be modified to expand the inclusion of drugs in class 1 based on transporter-enzyme interplay. In: AAPS Annual Meeting, 2006, San Antonio. San Antonio: University of California, 2006. Available at: <www.aapspharmaceutica.com/meetings/files/103/ LesBenetChallengesRoundtableinBCS.pdf $>$. Accessed on: 20 Jun 2015.

AGÊNCIA NACIONAL DE VIGILÂNCIA SANITÁRIA. ANVISA. Resolução RE no 1, 29 de julho de 2005. Publicação do Guia para a Realização de Estudos de Estabilidade. Diário Oficial da União, Poder Executivo, Brasília, DF, 1 Agosto 2005.

\section{AGÊNCIA NACIONAL DE VIGILÂNCIA SANITÁRIA.} ANVISA. Resolução RDC no 49, de 23 de novembro de 2010. Aprova a $5^{\mathrm{a}}$ edição da Farmacopéia Brasileira. Diário Oficial da União, Poder Executivo, Brasília, DF, 24 Novembro 2010.

\section{AGÊNCIA NACIONAL DE VIGILÂNCIA SANITÁRIA.} ANVISA. Resolução RDC nº 58, 20 de dezembro de 2013. Estabelece parâmetros para a notificação, identificação e qualificação de produtos de degradação em medicamentos com substâncias ativas sintéticas e semissintéticas, classificados como novos, genéricos e similares, e dá outras providências. Diário Oficial da União, Poder Executivo, Brasília, DF, 23 Dezembro 2013.
BROWN, T.L.; JUNIOR, H.E.L.; BURSTEN, B.E.; BURDGE, J.R. Chemistry central science. 9. ed. São Paulo: Pearson Prentice Hall, 2005.

CIDES, L.C.S.; ARAÚJO, A.A.S.; SANTOS-FILHO, M.; MATOS, J.R. Thermal behaviour, compatibility study and decomposition kinetics of glimepiride under isothermal and non-isothermal conditions. J. Therm. Anal. Calorim., v.84, n.2, p.441-445, 2006.

JAIN, P.S.; JIVANI, H.N.; KHATAL, R.N.; SURANA, S.J. Stability-indicating HPLC determination of ciprofibrate in bulk drug and pharmaceutical dosage form. Chem. Ind. Chem. Eng. Quart., v.18, n.1, p.95-101, 2012.

KUMBHAR, S.T.; LONI, A.B.; KOTHALI, V. Development and validation of stability indicating LC method for the estimation of fenofibrate. W. J. Pharm. Pharmac. Sci., v.2, n.5, p.4061-4078, 2013.

MCMURRY, J. Organic Chemistry. 9. ed. USA: Cengage Learning, 2015.

NASCIMENTO, G.N.L.; ROSA, D.L.; NISHIJO, H.; AVERSIFERREIRA, T.A. Validation of a spectrophotometric method to determine ciprofibrate content in tablets. Braz. J. Pharm. Sci., v.47, n.1, p.23-29, 2011.

RIBANI, M.; BOTTOLI, C.B.G.; COLLINS, C.H.; JARDIM,I. C.S.F.; MELO, L.F.C. Validation of chromatographic methods and electrophoretic. Quím. Nov., v.27, n.5, p.771780, 2004. 
SALAMA, F.M.M.; NASSAR, M.W.I.; SHARAF EL-DIN, M.M.K.; ATTIA, K.A.M.; KADDAH, M.Y. Detemination of fenofibrate and the degradation product using simultaneous UV-derivate spectrometric method and HPLC. Am. J. Anal. Chem., v.2, p.332-343, 2011.

SCHULZ, I. Treatment of dyslipidemia: how and when to combine lipid lowering drugs. Arq. Bras. Endoc. Metab., v.50, n.2, p.344-359, 2006.

SILVA, K.E.R.; ALVES, L.D.S.; SOARES, M.F.R.; PASSOS, R.C.S.; FARIA, A.R.; ROLIM NETO, P.J. Models for assessing the stability of drugs and medicines for the pharmaceutical industry. J. Bas. Appl. Sci., v.30, n.2, p.18, 2009.

THE UNITED STATES PHARMACOPOEIA. USP. 37. ed. Rockville: United States Pharmacopeial Convention, 2014.
WEI, Z.; BING-REN, X.; YING, Z.; LIYAN, Y.; TENG, W.; CAI-YUN, W. HPLC method for the determination of bezafibrate in human plasma and application to a pharmacokinetic study of bezafibrate dispersible tablet. $J$. Chromatogr. Sci., v.46, n.10, p.844-847, 2008.

YOSHIDA, M.I.; LIMA GOMES, E.L.; VIANNA-SOARES, C.D.; CUNHA, A.F.; OLIVEIRA, M.A. Thermal analysis applied to verapamil hydrochloride characterization in pharmaceutical formulations. Molecules, v.15, p.24392452, 2010.

YOSHIDA, M.I.; LIMA GOMES, E.L.; VIANNA-SOARES, C.D.; OLIVEIRA, M.A. Thermal behavior study and decomposition kinetics of amiodarone hydrochloride under isothermal conditions. Drug Dev. Ind. Pharm., early online edition, p.1-10, 2011.

Received for publication on $19^{\text {th }}$ October 2015 Accepted for publication on $15^{\text {th }}$ August 2016 
